The Family Office 



\title{
THE FAMILY
}

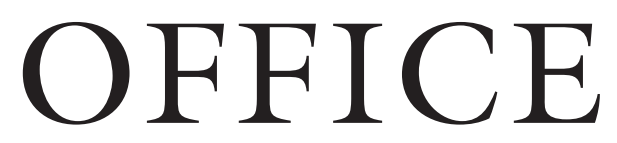

A Comprehensive Guide for Advisers,

Practitioners, and Students

\author{
William I. Woodson and \\ Edward V. Marshall
}

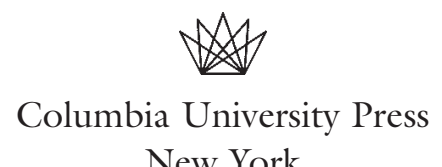

New York 


\section{Columbia University Press \\ Publishers Since 1893 \\ New York Chichester, West Sussex \\ cup.columbia.edu}

Copyright (C) 2021 Rybat Advisors, LLC.

All rights reserved

Library of Congress Cataloging-in-Publication Data

Names: Woodson, William I., author. | Marshall, Edward V., author.

Title: The family office : a comprehensive guide for advisers, practitioners, and students / William I. Woodson and Edward V. Marshall.

Description: New York : Columbia University Press, [2021] | Includes

bibliographical references and index.

Identifiers: LCCN 2021004239 (print) | LCCN 2021004240 (ebook) |

ISBN 9780231200622 (hardback) | ISBN 9780231553711 (ebook)

Subjects: LCSH: Investment advisors. | Financial planners. | Financial

services industry. | Families-Economic aspects. | Rich people-Finance,

Personal. | Wealth-Management.

Classification: LCC HG4621 .W66 2021 (print) |

LCC HG4621 (ebook) | DDC 332.6-dc23

LC record available at https://lccn.loc.gov/2021004239

LC ebook record available at https://lccn.loc.gov/2021004240

Columbia University Press books are printed on permanent and durable acid-free paper.

Printed in the United States of America

Cover design: Milenda Nan Ok Lee

Cover image: KjellBrynildsen (C) iStock 
Information is not knowledge. The only source of knowledge is experience. You need experience to gain wisdom.

-Albert Einstein

Главное, самому себе не лгите.

—Fyodor Mikhailovich Dostoyevsky 

I dedicate this book to my beautiful wife, Cynthia, whose patience and support know no bounds; my wonderful children, Olivia, Chase, Jack, and Henry, who challenge and inspire me; and my many great bosses, colleagues, and clients from whom I've learned all that I have to share.

-Bill Woodson

Once again to Natalia

And to Isabella, Veronika, Emilia, and Evelina

Many Fêtes

$-\mathrm{EVM}$ 
